\title{
TOURISM EVENTS AND THE NATURE OF STAKEHOLDER POWER
}

\author{
FIDELLA TIEW,* KIRSTEN HOLMES,† AND NIGEL DE BUSSY† \\ *Faculty of Business and Humanities, Curtin University, Sarawak, Malaysia \\ †School of Marketing, Curtin University, Perth, Western Australia
}

\begin{abstract}
This exploratory case study examines the power relations among the stakeholders of a tourism event in Borneo. It examines the sources of stakeholder power and the pattern of interdependence of various stakeholders, primarily based on interviews with event managers and stakeholders, as well as field visits. An analysis of the different types and amount of resource control, dependency, and network centrality resulted in four different categories of stakeholder power patterns-executive, asset based, referral, and diffuse stakeholders. The study also found that resource-based power was the primary source of power, whereas network-based power was a secondary and supplementary source. The case study revealed that the salience of event stakeholders based on their power was highly variable due to the different types of power that they had. This article contributes to the literature of event tourism, a typology of the event stakeholder powers in a predominately government-owned music festival, and offered practical suggestions to event management. It also advances the stakeholder power concept within event tourism studies.
\end{abstract}

Key words: Tourism event; Stakeholder power; Resource dependency; Network centrality; Stakeholder salience

\section{Introduction}

This exploratory case study examines the nature of stakeholder power in the organization of a largescale music festival to find out which stakeholders are more or less powerful, and why. Power, legitimacy, and urgency are attributes of stakeholder identification and salience advocated by Mitchell, Agle, and Wood (1997). A study of sporting events found that power has the most important effect on stakeholder salience (Parent \& Deephouse, 2007).
Stakeholders can acquire power depending on their individual attributes and their structural position (Pfeffer, 1992), and these different bases of power may have different impacts on stakeholder salience. This study's objective is to propose a categorization of stakeholder power in the tourism events setting relating resource-based and network-based power, with a view to advancing the stakeholder power concept within event tourism studies.

From the event studies literature (e.g., Getz, Andersson, \& Larson, 2007; Parent \& Deephouse, 
2007; Reid, 2011; Xue \& Mason, 2011) it is clear that staging tourism events requires input and collaboration from numerous actors and stakeholders from the public and private sectors, respectively. Empirical investigations reveal that in the process of managing collaborative tourism activities, power is ubiquitous in every system of relations (see, e.g., Cooper, Scott, \& Baggio 2009; Jamal \& Getz, 1995; Sheehan, Ritchie, \& Hudson, 2007) featuring differences in both the amount and the type of power that different stakeholders hold (Beritelli \& Laesser, 2011; Ford, Wang, \& Vestal, 2012; Hazra, Fletcher, \& Wilkes, 2014; Marzano \& Scott, 2009; Reed, 1997). Previous studies have explicitly addressed the concept of power within tourism planning and networks, as well as destination marketing and management, yet only a few studies (e.g., Andersson \& Getz, 2007; Clarke \& Jepson, 2011; Larson, 2002) have analyzed the power relationships within the context of events and festivals. Although stakeholder power relations are a nascent theme within event tourism research, there is a paucity of studies on emerging event destinations such as those in Southeast Asia.

In the endeavor to study stakeholder power relations in event organizations it is necessary to understand where power comes from and how these sources of power become embedded in stakeholder relationships and consequently in networks. The theoretical concepts commonly applied and developed in studies of stakeholder power relations include resource dependence theory (Pfeffer \& Salancik, 2003) and network theory (Rowley, 1997). Using a case study approach (Yin, 2003), this article provides an understanding of event stakeholder power relations among the stakeholders of a music festival in Borneo by analyzing the interactions between resource control, dependency, and network position, all of which have not been adequately addressed to date in event studies. The two central questions to be examined are:

1. Where does event stakeholders' power come from?

2. What is the pattern of interdependence of various stakeholders in events?

The following section outlines extant research on event stakeholder categorization and stakeholder power, highlighting resource dependency (Pfeffer \& Salancik, 2003) and network centrality concepts (Rowley, 1997). Studies on event network power are reported next, followed by a research methods section. In the findings section, using network- versus resource-based power, four stakeholder power patterns are identified and analyzed. These are executive, asset-based, referral, and diffuse stakeholders. Finally, the theoretical contribution, implications for event management, and limitations and further research ideas are discussed.

\section{Literature Review}

\section{Identifying Event Stakeholders}

R. E. Freeman's (1984) ambiguous definition of a stakeholder is "any group or individual who can affect or is affected by the achievement of the organisation's objectives” (p. 46). It has created an intellectual debate on the broad versus narrow definition of a stakeholder. Based upon Freeman's definition, Mitchell et al. (1997) offered a theory of stakeholder identification and salience based on the possession of one, two, or all three attributes of power, legitimacy, and urgency. It suggested that the more attributes a stakeholder has, the greater its salience, and thus the stakeholder deserves more managerial attention.

A number of attempts have been made to map event stakeholders from different perspectives. Getz et al. (2007) presented seven major groups of festival stakeholders based on their roles and responsibilities - the festival organization, coproducers, facilitators, allies and collaborators, regulators, suppliers and venues, and the audience and impacted. Similarly, Allen, O’Toole, Harris, and McDonnell (2011) offered the "relation of stakeholders to events" perspective, identifying six major event stakeholder groups (p. 127). These are the "host organization," the "host community," the "coworkers," the "event sponsors," the "media," and the "participants and spectators." On the other hand, Spiropoulos, Gargalianos, and Sotiriadou (2006) categorized ethnic festival stakeholders from a functional role (i.e., marketing, administration, and production) perspective. Alternatively, Reid and Arcodia (2002) adopted a similar framework to Clarkson (1995), prioritizing primary versus secondary stakeholders based upon their 
roles and perceptions of risk. They distinguished the primary event stakeholders as people who have direct involvement and are essential to event survival, where secondary stakeholders do not have such a direct connection with, and impact on, the event. These studies infer that role differentiation in the event organization involves power differences, but they do not analyze stakeholder power further. As this article is exploratory in nature, categorization of stakeholders takes a broad approach so that no stakeholders are excluded and so provides a more holistic view of the stakeholders involved in the event tourism.

\section{Stakeholder Power}

Power is the (potential) capability of stakeholders to influence others to bring about desired outcomes (Pfeffer \& Salancik, 2003) in a relationship through coercive, utilitarian, or normative means (Etzioni, 1964). Savage, Nix, Whitehead, and Blair (1991) added that capacity, opportunity, and willingness to threaten or cooperate are a function of a stakeholder's relative power, and they identified four stakeholder relationships-supportive, mixed blessing, nonsupportive, and marginal stakeholders. Mitchell et al. (1997) argued that stakeholder power may be explained using resource dependency theory (Pfeffer \& Salancik, 2003), as organizations are interdependent for resources and thus survival. In contrast, Rowley (1997) has defined stakeholder power in terms of network structure and position. Most tourism studies have examined stakeholder power either using resource dependency theory (see Ford, Peeper, \& Gresock, 2009; Getz \& Andersson, 2010; Sheehan et al., 2007) or network theory (see Beritelli \& Laesser, 2011; Cooper et al., 2009) separately. Pajunen's (2006) insightful integration of resource dependencies and network positions offers a matrix of stakeholder power identification, and provides a valuable framework for studying stakeholder power in tourism. Supporting Pajunen's approach, Hazra et al. (2014) evaluate stakeholder power relationships in a tourism destination by looking at both resource and network-based power. However, Hazra et al. (2014) viewed these two bases of power as relational attributes, having equal forms of influence. Their analysis did not examine the relative levels of stakeholder power.
This study adapts Pajunen's (2006) matrix and aims to develop a typology of stakeholders' power in events. So far, no event tourism studies have integrated resource dependency and network position to analyze event stakeholder power and this study seeks to fill that gap. Knowing how different resource control and network positions coconstruct stakeholders' power in events will enable event organizers to identify salient stakeholders and to whom the event managers should pay attention.

\section{Resource Dependency}

Power and resources are closely related. Power is afforded to stakeholders controlling essential and critical resources (Mitchell et al., 1997) upon which organizations depend for growth and competitiveness (Donaldson \& Preston, 1995; Pfeffer \& Salancik, 2003). Resources can be almost anything that is perceived as valuable (Pfeffer, 1992), either tangible (e.g., money, material supplies, manpower, real estate) or intangible (e.g., knowledge, skill, reputation, image, authority), as well as individual attributes such as competence, innovativeness, and trustworthiness (Church \& Coles, 2007; Marzano \& Scott, 2009; Pfeffer \& Salancik, 2003). A recent study on power distributions in tourism networks by Ford et al. (2012) indicated that reputation, allies, and hierarchy were the source of influence. Beritelli and Laesser (2011) and Clarke and Jepson (2011) identified knowledge and competence as resources in the exercise of power. However, mere possession of resources does not make one powerful. According to Pfeffer and Salancik (2003), the ability to regulate or control the access, possession, allocation, and use of resources forms the basis of power. Above all, a strategy for gaining power makes the resources that one controls more important, valuable, unique, or nonsubstitutable. Thus, a stakeholder in control of essential and critical resources needed to achieve the event goals possesses a power advantage relative to other dependent stakeholders (Mitchell et al., 1997). The pattern of dependence and interdependence among stakeholders for critical resources determines the power distribution in the stakeholder network (Ford et al., 2012; Sheehan et al., 2007). For instance, the survival of an event organization depends on its ability to acquire support and resources from different 
stakeholders (Getz, 2002; Getz et al., 2007; Reid, 2011). Such dependence of an event on external stakeholders for resources gives those stakeholders leverage and "power" over an event. In their study of festival organizations across four countries, Getz and Andersson (2010) distinguished four dependency patterns: venue first, government first, customer first, and sponsors first. They found that the festivals studied were not overly dependent on any group of private sector stakeholders, but perceived dependence on the government sector was prevalent.

\section{Network Centrality}

Rowley's (1997) network perspective of stakeholder power "refers to power obtained through the network's structure, as opposed to power gained through individual attributes” (p. 898). Network centrality measures a stakeholder's number of direct links to others (degree), independent access to others (closeness), and control over others (betweenness) in the network (L. C. Freeman, 1979; Rowley, 1997). The more a stakeholder is connected to other stakeholders and the shorter the communication paths to the focal organization and all others in the network, the more central is that stakeholder. It is suggested that centrally positioned stakeholders have power advantages given that they control information and knowledge flow in the system or have access to other resources potentially available within the network (Rowley, 1997). Information and knowledge are important tourism resources in the networks used by all stakeholders to collectively market their destination and at the same time compete with each other for individual benefits (Hazra et al., 2014). Such coexistence of cooperation and competition (coopetition) relationships with each other is regarded as an efficient way of achieving success for individual benefits as well as common benefits (Wang \& Krakover, 2008). Centrally positioned stakeholders have direct influence on the exchange of resources in this "coopetition” relationship, whereas peripheral stakeholders tend to depend on other stakeholders to access other regions of the network (Rowley, 1997). Nonetheless, Cooper et al. (2009) examined how the position of individual stakeholders in a destination network is related to their perceived salience and concluded that the network position is only a partial indicator of perceived stakeholder salience. Their study implied that stakeholders' contribution to the diffusion of knowledge, communication, and decision making in the network is what made them salient.

\section{Event Network Powers}

Tourism event networks are networks of event organizers, participants, audiences, services suppliers, travel trade intermediaries who are interrelated in the delivery of a specific event experience (Getz, 2005). Yearly, the networks may come together for a specific period of time then break up. The entries and exits of actors may result in a continuous change of stakeholders in the network (Larson, 2009). The metaphor of a "political market square" is used to describe interaction between events' stakeholders (Larson, 2002; Larson \& Wikstrom, 2001), highlighting network dynamics and different strategies. More recently, by applying the concepts of "access," “interaction,” and “change dynamics,” Larson (2009) further developed her metaphor to distinguish different types of event networks. However, her study only described the characteristics of the political processes in event networks and how they affect the events without examining the actors' interdependency relationship in the event networks. Similarly, Izzo, Bonetti, and Masiello (2012) and Prebensen (2010) went deeper into network analysis to provide understanding of how network structure and relationships affect the success of the event and its outcomes on local development. Conversely, drawing from stakeholder and resource dependency theory, Andersson and Getz (2007) studied how the power structure within a festival's network influences its cost and revenue. Their study concluded that stronger stakeholders can be costly over time compared to the weaker stakeholders because of their stronger negotiation position in bargaining over pricing.

Although there is substantial research on the power held by different stakeholders within the context of an organization or a destination (Beritelli \& Laesser, 2011; Marzano \& Scott, 2009; Nunkoo \& Ramkissoon, 2012), there is a paucity of work examining event stakeholders' power. Previous studies examine power networks among event stakeholders but do not examine the different kinds of power that 
event stakeholders have in terms of their resource control and network position. The notion of resourcebased power and network-based power have yet to be adequately integrated into a single framework in research on stakeholder power relations in tourism events and this research seeks to address that gap.

\section{Research Methodology}

To address the research questions, an interpretivist philosophy and qualitative means of inquiry using a case study was adopted (Saunders, Lewis, \& Thornhill, 2009). A case study approach was used in this study as it is ideal for exploring complex social relations in an event (Miles \& Huberman, 1994) and understanding a real-life phenomenon in depth (Yin, 2009). The value of using a case study approach in research is well documented (Myers, 2009; Swanborn, 2010; Yin, 2003). In fact, previous studies of event stakeholders have typically used a case study approach (e.g., Getz et al., 2007; Prebensen, 2010; Spiropoulos et al., 2006; Xue \& Mason, 2011). An interpretive and qualitative means of inquiry was the most appropriate approach for illuminating the multistakeholders' relationships within a rich cultural system in Borneo, providing the necessary depth and richness to the study (Patton, 2002).

\section{Case Study}

This study uses data collected from a ticketed music festival in Borneo organized by a tourism board. Annually, a project team consisting of staff members from the tourism board is formed to organize the event. Members of this project team are considered to be the event managers in this case study. The event was introduced as a tourism product to a local city in 2006, aiming to position the city on the "tourism map" via music, fostering a positive city image, and at the same time serving as a "springboard" for promoting hinterland tourism destinations in Borneo. Every year an eclectic line up of regionally and internationally recognized jazz musicians play a diverse range of jazz genres at the festival over 2 nights, drawing 6,000 to 8,000 festival goers. Besides locals and expatriates working in Borneo, the event also attracts international visitors-largely from Singapore, Peninsula Malaysia, Australia, and some from
Europe and the Americas. As well as enjoying the musical performances, the festival goers can also buy a wide selection of food and beverages, souvenirs, and craft products offered by vendors at the festival venue.

This music festival was chosen based on pragmatic criteria (Swanborn, 2010). First, the proximity of the location of the researcher meant that the researcher was able to attend several editions of the festival. Second, the researcher obtained the access needed to collect the case study evidence due to a preexisting relationship with the event (Myers, 2009), where the researcher had allocated student volunteers to assist at the event. This music festival is one of the top tourism events in Borneo and represents a typical tourism event (Yin, 2009), which was “created” by a tourism organization to develop and promote regional tourism, and has inputs from multiple stakeholders.

\section{Sampling}

Getz et al.'s (2007) list of key stakeholders for an event was utilized as the basis for the stakeholder sampling framework as it includes a diverse range of festival stakeholder types. Accordingly, the event managers were interviewed first.

Interviews with event managers revealed which stakeholders they interacted with. The event managers were then asked to refer the researchers to these stakeholders for subsequent interviews. To avoid managerial and gatekeeper bias, some stakeholders were identified from the event websites, press releases, and at the event site, and then selected on a random basis and contacted to solicit their participation in the study (Myers, 2009). Examining power collectively from both the organizers' and stakeholders' perspectives gives a more complete picture of the stakeholder relationships at the event (Kim, Boo, \& Kim, 2013).

In total, 14 semistructured interviews were conducted with persons representing different organizations involved in producing the event. These included four event managers, one hotel manager (host venue), two volunteers (one local and one international), two vendors, one corporate sponsor, one travel business, one media representative (blogger), one musician, and one representative from the local government. 


\section{Data Collection}

From the 14 informants, nine had been involved with the event since its beginning. With a few exceptions, participants were interviewed at their offices or event site. Open-ended questions were used in the semistructured interviews to gain an understanding of the stakeholders' interdependent relationships in the event network (Saunders et al., 2009). All participants were asked the same questions, except the event managers who were additionally asked to list and rank the stakeholders involved. Questions were asked about the participants' roles and involvement in the event, how and why they became involved, and their relationships with one another. The participants were encouraged to give specific examples of issues or incidents developed in these relationships (Yin, 2003). Accordingly, by asking the participants what stakeholders were important for organizing the event, influencing the event success, and on whom the event depends for survival, the perception of stakeholder resource power in the music festival was elicited (Parent \& Deephouse, 2007). To capture the stakeholder network power, participants were asked to identify who, when, how, and how often they interacted in the process of organizing the event, and describe their communication relationships with one another in terms of information and knowledge exchange in the network (Cooper et al., 2009; Gulati, 1999). The interviews lasted from about 30 to 90 minutes, were recorded, and subsequently transcribed for analysis. Interview reports were disseminated to the participants involved, to cross-check for any discrepancies in the data. This participant check process (Lincoln \& Guba, 1985) helps to validate the accuracy of findings (Creswell, 2003).

Besides interviews, field visits to the event created the opportunity for direct observation of stakeholder behaviors and interactions (Yin, 2009). Casual data collection activities included talking to the stakeholders and assessing the protocol at the event site to further collect evidence. Data were recorded in a field note journal. Other documentary evidence was also used to supplement the data from the interviews and field visits. For example, the event websites have provided useful information on the event background and organizing team; informed who the sponsors, partners, and performers were; outlined media accreditation and volunteer recruitment policy and process. Press releases were used to gauge which and why stakeholders are newsworthy, prominent, reputable, and influential. Other archival publications and e-mails between stakeholders gave some indication of ties within the event network. Use of multiple empirical evidence helps to obtain a more complete and precise perception of the event and to enhance the reliability of the research (Eisenhardt, 1989; Yin, 2009). A further rationale for this approach is the development of converging lines of inquiry, a process of triangulation and corroboration making the findings more convincing and accurate if they are based on several different sources (Patton, 2002; Yin, 2009).

\section{Data Analysis}

All secondary sources and interview data were uploaded to NVivo 10 for textual analysis and coding. Various sources of data were identified, coded, and analyzed to give an aggregated view of the stakeholder power relationships of the event (Saldana, 2013). Data were carefully read and reread in order to establish content and meaning (Miles \& Huberman, 1994). Data that "look like" resource power or network structure were coded and categorized according to stakeholder groups and power types (Lincoln \& Guba, 1985). To distinguish the relative network power, data were subcategorized under "central" or "marginal." These two concepts were adapted from Cooper et al. (2009). A stakeholder who has multiple direct numbers of links, and falls between pairs of other stakeholders in the event communication network, was categorized as having "central" network power (L. C. Freeman, 1979; Rowley, 1997). Stakeholders with single or no direct link and who do not fall between others' communication paths were categorized as "marginal." Similarly, the nature of resource power was differentiated into "critical" or "replaceable." These two concepts were modified from Getz et al. (2007) to examine how important the resource is to the staging of the event, the extent the resource is critical and essential, or replaceable in nature, and the availability of alternate suppliers or substitutes (Andersson \& Getz, 2007). The two types of power 
were then combined in a matrix to propose a typology of stakeholder power.

\section{Findings}

The first part of the study sought to identify which stakeholders were involved and what their roles in the event organization were. Next, the event network configuration was considered, followed by an evaluation of the nature of stakeholder power from both the resource and network dimensions. These findings are supported with direct quotations from the interviews. The interviewees have been given pseudonyms Participant 1, Participant 2, etc. Table 1 provides a key to the different participants interviewed in this case study.

The case study music festival was founded and owned by a tourism board (i.e., an agency that comes under the remit of the state tourism ministry). As a result, many people perceived it as a "government" event, organized by a "permanent" institution. In the interviews, the event managers used a narrow definition of event stakeholders compared to R. E. Freeman's (1984) broad definition. Stakeholders were seen by the event managers as groups of people whose involvement and contribution were required in event production or those who benefited from the event. This is similar to that of the primary event stakeholders as defined by Reid and Arcodia (2002). The data highlighted a range of actors and agencies directly involved in staging the festival. Eleven groups of stakeholders were identified, and their roles and representation in the case study are summarized in Table 1.

\section{Network Configuration}

The evidence reveals that many of these key stakeholders engaged themselves in the event on an annual basis. As a result, network membership has been stable. This also suggests that the planning and implementation of work was exercised by an established group of stakeholders. Most of the participants noticed that the lead time required to organize the event had reduced over the years, as most of the people involved had experience, and knew their functions and tasks well. Figure 1 illustrates the network structure of the festival. Each of the identified stakeholders has a direct relationship with the event organizer except the audiences and vendors.

Table 1

Event Stakeholders and Roles

\begin{tabular}{|c|c|}
\hline Stakeholders & Participants in the Case Study \\
\hline $\begin{array}{l}\text { Event owner and organizer } \\
\text { tourism board directors, staff, project team }\end{array}$ & $\begin{array}{r}\text { Manager } 1 \text { (Participant 1); manager } 2 \text { (Participant 2); } \\
\text { manager } 3 \text { (Participant 3); manager } 4 \text { (Participant 4) }\end{array}$ \\
\hline $\begin{array}{l}\text { State, local government, and public authorities } \\
\text { financer and regulator }\end{array}$ & Local government representative (Participant 14) \\
\hline $\begin{array}{l}\text { Home venue supplier } \\
\text { hotel management and property owner }\end{array}$ & Hotel manager (Participant 13) \\
\hline $\begin{array}{l}\text { Corporate sponsors } \\
\text { either in cash or in kind }\end{array}$ & Sponsor (Participant 12) \\
\hline $\begin{array}{l}\text { Volunteer } \\
\text { mainly students from colleges and universities }\end{array}$ & $\begin{array}{l}\text { Local volunteer (Participant 5); international volunteer } \\
\text { (Participant 6) }\end{array}$ \\
\hline $\begin{array}{l}\text { Performers } \\
\quad \text { local and international musicians/bands }\end{array}$ & Local musician (Participant 11) \\
\hline $\begin{array}{l}\text { Media } \\
\text { international and local journalists, bloggers, broadcasters }\end{array}$ & Blogger (Participant 10) \\
\hline $\begin{array}{l}\text { Tourism businesses } \\
\text { travel agents, airlines, hotels, ground transports }\end{array}$ & Travel agent (Participant 9) \\
\hline $\begin{array}{l}\text { Paid service suppliers } \\
\text { tents, stage, audio-visual equipment, ticketing agents }\end{array}$ & Informally talked to during field visit \\
\hline $\begin{array}{l}\text { Vendors } \\
\text { food and craft mart }\end{array}$ & Vendor 1 (Participant 7); vendor 2 (Participant 8) \\
\hline $\begin{array}{l}\text { Audiences } \\
\text { local and expatriate population, regional and international visitors }\end{array}$ & Informally talked to during field visit \\
\hline
\end{tabular}




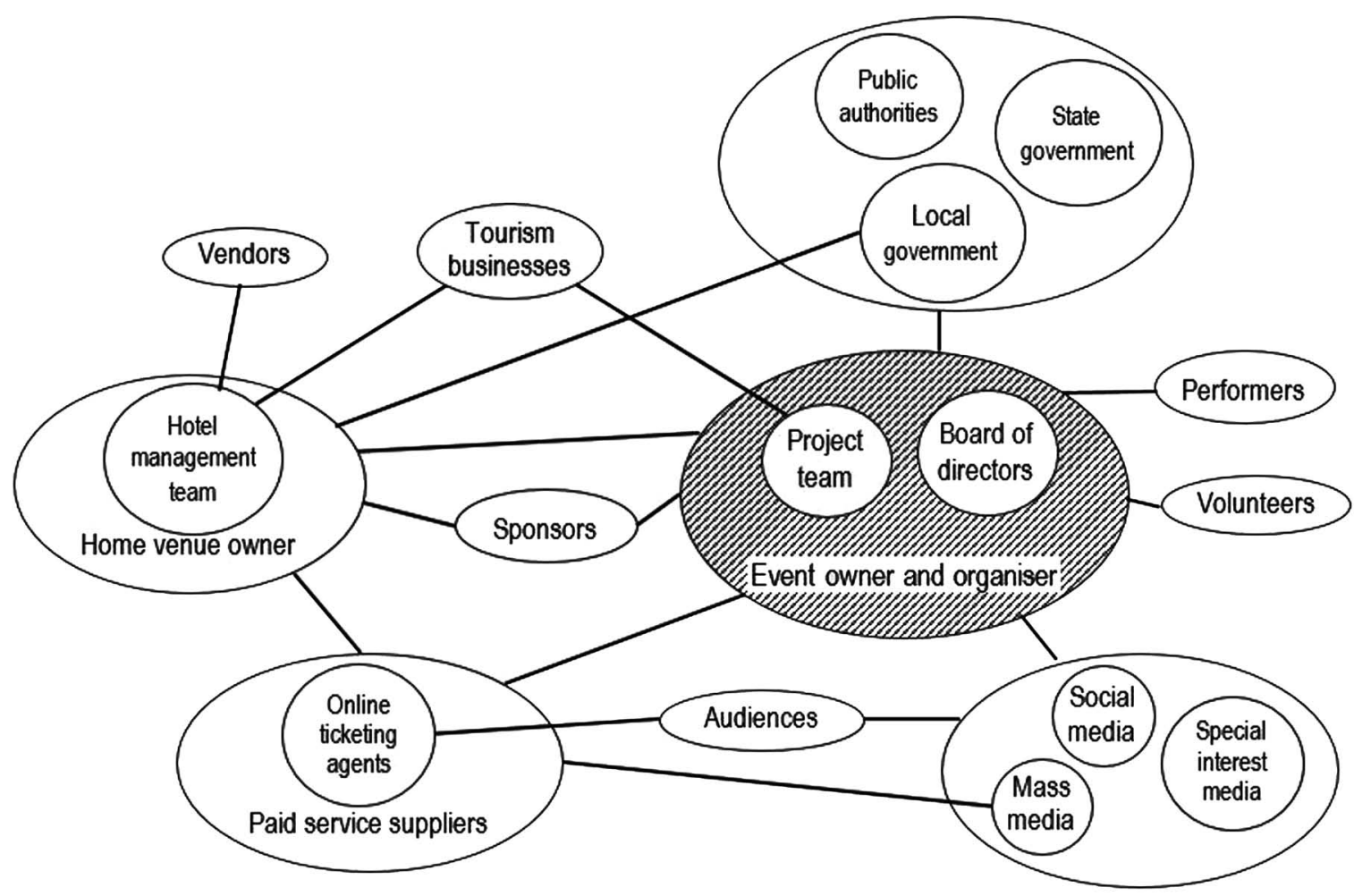

Figure 1. Event network structure.

\section{Dual Powers Configuration}

The findings indicate that stakeholders do not have equal power in event organization due to their differences in resource ownership and network position. A stakeholder could have both types of power, just one, or neither. Stakeholders can be categorized into four groups based on the nature of power they display. We have named stakeholders with both types of power the "executive stakeholders," stakeholders with resource-based power the "asset-based stakeholders," stakeholders with network-based power the "referral stakeholder," and stakeholders with neither power the "diffuse stakeholders.” The following sections will discuss the four groups in sequence.

\section{Executive Stakeholders}

In the case study, stakeholders who owned or have access to critical resources and had central network positions were the most powerful. They held executive power in the organization of event. The resources that they brought to the event were almost irreplaceable. They could have a major influence and impact on decisions, and had the ability to get things done according to their rules. They were in control of the actual execution of the event when it came to planning, marketing, and organizing the event. The stakeholders who held such power were, respectively, the event owner, the government and public authorities, and the home venue supplier.

Event Owner. All participants perceived the tourism board as having the strongest power position and legitimate authority to create, coordinate, and control the event development, marketing, and production in the state. The tourism board represented the focal organization in the tourism industry network and had relationships with most of the tourism players. With their institutional and central network power in the tourism industry, the tourism board was able to secure and deploy resource supplies in 
both the event network and at the destination marketplace on an ongoing basis.

As the organizer, the tourism board was in control of the festival's branding efforts. The name and logo of the event were copyrighted. Every year the event concept, design, programming, and budget were determined by the project team and approved by their board of directors. The festival was supported substantially by ministry funding. All four managers interviewed explicitly mentioned that funding and grants from the tourism ministry were the most important factor in sustaining the event production. For example, when asked the question, "Who do you think the event depends on for survival?” Participant 3 responded:

The ministry grant, of course! Because this event as much as we talked about sponsorships and ticket revenue, the amount was never enough to cover the cost ... before we start, a project planning paper and budget has to be approved by the board of directors, whereby it actually goes through the ministry. With the approved figures and concept, then we formed the project team to start organizing the event.

The festival was promoted internationally through the tourism board's national and global network. Most of the interviewed stakeholders such as the volunteers, the bloggers, and the performers were proud to be associated with the event due to its international reputation and image. As the event organizer, the tourism board provided event leadership, committed and skilled staff, and material supplies to the festival. They had a significant role in the direction and related success or failure of the event.

Governments and Public Authorities. This group of stakeholders was an important local partner at the destination level to facilitate the smooth running of the festival. The state government was the financer of the event. The local government sponsored publicity and other material required at the destination level, and helped to mobilize concerned public authorities such as police, health, medical team, immigration department, and airport authority. The event depended on this group of stakeholders mainly due to the need for technical compliance. With their respective institutional power, the event organizer needed to have cordial working relations with them in order to get the necessary approval and services.
Home Venue Supplier. The home venue of the festival was on a private beach-front hotel. According to the event managers, this hotel provided a nonsubstitutable ideal venue for the festival, and offered discounted room rates and free use of function facilities. The hotel assisted with the sourcing of vendors for the event and was evidently a powerful stakeholder. From the very start of the event, the hotel had been the only alcoholic beverage seller because it was held on their premises. Over the years, the event managers did consider moving the event to other venues, but failed to find a suitable alternative that could offer matching physical surroundings and ambience for the festival. As Participant 1 mentioned:

The hotel's ambience is still the best, and because of that ... they know that we need them a little bit more than they need us (laugh) ... that's where the market force detects, so there is a lot of time we tend to give in.

As the venue supplier, the hotel provided a wide variety of essential resources that were crucial to the major stakeholders (e.g., the event organizers, performers, foreign media, and volunteers). Through several years of developing a working relationship, the hotel gained the trust of the organizer in delivering the standard required for the event. Thus, in recent years, the hotel had been entrusted by the organizer to manage the food and craft mart. They became the gatekeeper in the vendor selection process. Evidence indicates that there was a gradual increase in their monopoly in food and beverage sales while there was a decrease in the number of external vendor stores available on site over the years. Moreover, being a key tourism player in the event destination, the hotel was also considered as having network-based power within the local tourism industry, recognized by many event organizers as an ideal copartner in the event organization.

\section{Asset-Based Stakeholders}

The study also indicates that stakeholders who contributed critical and essential resources to the event were important and influential. This group of stakeholders included corporate sponsors, volunteers, and performers. This group could choose to give or withhold their resources. The event was highly dependent 
on these resources, without which there may be substantial impacts on the event production. These stakeholders might not possess network power in the event organization because they did not have many connections or interactions with other stakeholders. However, because of their valuable contribution to the event, they had the ability to leverage the event to their advantage, be it in the economic, social, political, or personal domain. Examples of these will be given in the subsequent sections.

Corporate Sponsors. According to the event managers, finance was the most important resource needed to organize this nonprofit music festival. Corporate sponsors contributed critical resources in terms of cash sponsorship and some in-kind support. One manager commented that withdrawal of major sponsors would have impacted on the organization of the event because their sponsored amounts were quite substantial. These corporate sponsors were involved in the event either for financial or political reasons. For example, an alcoholic beverage company who gave cash sponsorship annually could monopolize the beer supply inside the festival area. On the other hand, a multinational energy company saw their long-term cash sponsorship as necessity for maintaining relationship with the government and achieving their company's goals. Participant 12 stated:

In the past we have contributed a lot to the progress of the city . . . we have a large number of foreign employees . . . to get these people to keep on working here, we have to help the government make the city an exciting place to live in ... creating, developing and progressing together with the government for mutual benefit.

In general, these corporate sponsors did not interact greatly with other stakeholders in the event network. They did not appear to interfere or exert any network power over the organization of the music festival.

Volunteers. This festival was highly dependent on volunteers to execute the logistics, technical, and operational aspects. A "Memorandum of Understanding" (MOU) was signed between the tourism board and higher education institutions in the destination cementing a partnership for internships and volunteer programs. Universities and colleges consistently supplied student volunteers needed for the event. This group is rewarded with meals and event t-shirts. The student volunteers often exhibited higher levels of performance to assigned tasks and were committed and trusted loyal supporters of the festival who returned annually to volunteer their services. As Participant 3 observed:

\section{We also grow students like Mr. X, he was with us since day 1 . Today we can actually leave him to run his own show. We don't need to guide him anymore ... he is like a member of our team.}

The event gave the student volunteers a learning platform and insight into event management. However, at the festival most volunteers do not have the opportunity to interact with other stakeholders in the network, except when performing tasks for the event. Among the important tasks performed by student volunteers are logistic arrangement, merchandise and ticket sales, backstage support, and event secretariat and media assistance.

Performers. High quality music attracts the event audience and is essential for achieving festival customer satisfaction. Every year, international and local bands were brought in to perform at the festival. A series of preevent media campaigns such as press releases, press conferences, and interviews about the bands were launched, creating much publicity for the event as well as for the performers. The performers were also given the opportunity to meet with their fans, and sell their music and merchandise at the event. Another highly attractive part of their participation was to earn a "free" trip to Borneo, a much sought after destination, and they enjoyed the fine hospitality arranged by the organizer. The performers relied primarily on their own talents to be in the event network, without having to depend on other stakeholders, and they required very little interaction with other stakeholders.

\section{Referral Stakeholders}

The study also revealed that stakeholders who did not hold and/or own critical resources as such, but had a more central network position, could 
potentially impact on the event attendance and image. They had access to the target audience, could influence their perception, and/or persuade them to attend the event. This group of stakeholders had network-based power because they channeled or distributed information about the event to others. The stakeholder deemed to have referral power is the media.

Media. The mass media was vital in terms of giving publicity and media coverage through press releases, media briefing, and performers' press conferences. They did not own any critical resources, but were positioned between the communication paths of other stakeholders. They facilitated the flow of information between the event organizer and the less central stakeholders, for example the audiences. A media familiarization trip was organized by the tourism board, bringing in both international and regional journalists and bloggers to encourage them to feature the event. The national radio and television station was invited to produce some live broadcasts of the event and also provide on-site announcers or master of ceremonies. This group of stakeholders was the mouthpiece for the event. However, with the advancement of social media, the dependency on mass media had reduced, as a manager affirmed:

Social media has certainly been empowering the event organizer to reach out to more people. It gives us the channel, the platform to showcase what we want to showcase, how we want to portray the event in the angle where things should be represented. Very often we are at the mercy of the third party media or traditional media, but social media gives us an opportunity to say our piece, to say what we want to say, in a way to have more control. (Participant 1)

\section{Diffuse Stakeholders}

In the case study, stakeholders who neither seemed to have control of critical resource nor had any ties with other stakeholders in the network were considered to be less powerful. To stay in the network, they tended to collaborate with stronger stakeholders, accepted the conditions, and cooperated for mutual benefit, or risk being excluded or replaced. Thus, they did not possess collective bargaining power and had to act within set parameters. The diffuse stakeholders included tourism businesses, paid service suppliers, vendors, and audiences.

Tourism Businesses. This group of stakeholders was the intended beneficiaries of the event. Businesses such as hotels, travel agents, and airlines were the services suppliers. These stakeholders could put together travel packages to attract tourists to promote the event with opportunities to increase their business revenue. A small number of proactive enterprises had their packages published on the event website. These businesses could capitalize on the festival to enhance their brand for future business. Unfortunately, most of the businesses only had a loosely connected relationship with the event, which might have impeded their effort in creating value for their businesses.

Paid Service Suppliers. Local contractors who built the stage and set up tents within the festival grounds were considered to have limited power. They did not appear to have control of more than one type of resource. Their relationship with the event organizer was transactional and replaceable in nature. They compete to win the business annually and any substandard service quality would result in their contract being discontinued and service replaced. Even though the event could be an important source of income for their businesses, they did not interact with stakeholders in the network other than the organizer and venue supplier.

Vendors. Similarly, entrepreneurs who rented booths to sell food and crafts at the event were considered not powerful because they could be easily substituted. None of the vendors controlled a unique resource. Even though the food vendors' variety and service quality influenced the eventgoers' experience (Lee \& Beeler, 2009), they were a powerless stakeholder at the event. They applied for their place at the event and needed to abide by the rules and regulations set by the organizer and venue supplier. The event provided an additional avenue for these small local businesses to promote their products as well as served as an alternate source of income. Evidence suggested that these 
vendors were generally passive in voicing their interest within the festival. Some chose to leave the event if they felt little direct benefit from it. They only had task-related interaction with event goers, and did not have any relationship with other stakeholders in the network.

Audiences. The organizer did mention that the audience was important and they conducted audience surveys to improve the operations and marketing for their benefit. From the results it is clear that the main purpose of the event is to market the destination. The event relies heavily on public funding and is not profit orientated. Accordingly, the ticket price is considered a subsidized one, the purpose of the event predominantly being about entertainment. Further, quite a large portion of the audience attends the event using the free tickets issued by the corporate sponsors.

In summary, the interaction of resource control, dependency, and network position produced different types of stakeholder power. This influenced the relative power between the event organizer and its stakeholders. The above section discussed four types of stakeholder power, which are recapitulated in Figure 2. This provides a framework for understanding different stakeholder power in a tourism event, particularly in a context of a governmentowned musical festival.

\section{Discussion}

In their editorial review, Weber and Ali Knight (2012) commented that emergent festival and event destinations in the Asia region appear to have strong government support and subsidy. Similarly, Getz and Andersson (2010) found that perceived dependence on the public sector in the event industry was prevalent. This study agrees with their conclusion that government is an important and powerful stakeholder in event tourism. It is evident in this study that government, through their agencies, initiated and became involved in event production as a destination marketing strategy and public service to local people. The event analyzed in this article does not aim to make a profit for the owner, but for all the other stakeholders involved in the organization. From the preceding analysis, it is evident that event stakeholders do not have equal power in the event organization due to differences in resource ownership and network position, which may influence their ability to leverage the event for their organizational or personal benefits. More detailed examination of the nature of stakeholder power would help prepare the organizers to address issues arising from the imbalance of power. The following section will further discuss the theoretical and managerial implications of the proposed framework (Fig. 2), then the limitations of the research will be stated and suggestions for future research made.

\begin{tabular}{|c|c|c|c|}
\hline & 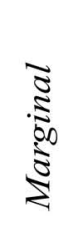 & $\begin{array}{l}\text { Asset-based Stakeholders } \\
\text { Corporate sponsors } \\
\text { Volunteers } \\
\text { Performers }\end{array}$ & $\begin{array}{l}\text { Diffuse Stakeholders } \\
\text { Tourism businesses } \\
\text { Vendors } \\
\text { Paid service suppliers } \\
\text { Audiences }\end{array}$ \\
\hline $\begin{array}{l}\text { Network- } \\
\text { based } \\
\text { power }\end{array}$ & 离 & $\begin{array}{l}\text { Executive Stakeholders } \\
\text { Owner/organiser } \\
\text { Home venue supplier } \\
\text { Governments \& public authorities }\end{array}$ & $\frac{\text { Referral Stakeholders }}{\text { Media }}$ \\
\hline
\end{tabular}

Resource-based power

Figure 2. Typology of event stakeholder power. 
This article is based on an exploratory case study and therefore the implications need to be considered in this light. Nevertheless, the article provides an understanding and modeling of event stakeholder power from resource ownership, dependency, and network position perspectives. Four different types of stakeholder power-executive, asset based, referral, and diffuse-have been identified and are used to propose a typology of event stakeholder powers to the literature of event tourism. It is probable that these power patterns will be similar in most predominantly government-owned tourism events in developing countries as they operate in a similar sociopolitical environment.

The findings show that a private venue supplier who has both resource and network power was categorized as a powerful executive stakeholder, together with the organizer, and the government and its agencies. Likewise, in his study, Pajunen (2006) acknowledged that the "governing stakeholders" have a direct influence on an organization's survival. This case study also affirmed Getz and Andersson's (2010) "venue-first" and "government-first" dependency relationship in festivals (p. 549). In their study the perceived dependency on public venues/facilities was the highest, but in this study it was a private-owned hotel, where the organizer and venue were mutually dependent. Furthermore, it is evident that power was concentrated within the organizer and a few big private entities. This study confirmed Marzano and Scott's (2009) and Cooper et al.'s (2009) propositions that only limited number of stakeholders were considered powerful within a tourism destination, and they tend to be larger in size, have larger marketing budgets, and have more skills and knowledge. Similarly, Izzo et al. (2012) found that the "core network" in festivals was made up of a few stakeholders, whereas the "extended network" was made up of a larger number of stakeholders. On the other hand, tourism authors such as Jamal and Getz (1995) and Beritelli and Laesser (2011) proposed that power in a tourism destination is diffused and decentralized.

The asset-based stakeholders from the private sector exert power based on various critical resources, in line with Etzioni's (1964) commentary on utilitarian power, which states that the assets involved can vary enormously. For corporate sponsors it might be cash, and volunteers and their time.
For performers, it is their talent and fame. Not all asset-based stakeholders are equal. Some sponsors have more cash or access to performers that have greater fame. Accordingly, they have more power to leverage. This reflects the power heterogeneity of an intrastakeholder group. Hazra et al. (2014) suggested that possession of assets as a source of power by the private sector tourism stakeholder was apparent. This study extends this by showing that it is a stakeholder's willingness to contribute the asset and be highly dependable that makes a stakeholder powerful.

The findings in this study contradict Beritelli and Laesser's (2011) conclusion, as they denied power stemming from material resources as being important. In fact, this study implies the two types of power may have differential impacts on stakeholder salience. Cooper et al.'s (2009) study found that network position was a partial indicator of perceived stakeholder salience, and the frequency of interaction did not correlate to the perceived importance of stakeholders. This study espouses that resource attributes have a direct relationship with power, whereas network position facilitated access to other stakeholders as source of power. Resource-based power was more important than network-based power in this study simply because event production is resource intensive. If there were no essential resources available there would be no event production. The event depends on the referral stakeholders, in this case the media, to inform, persuade, and remind its potential regional and local audiences of the event. This corroborates previous studies that have found the media to have a facilitating role, and which can make or break the event (Getz et al., 2007) and have the power to cocreate stakeholder values in events by attracting visitors (Prebensen, 2010). Rowley (1997) also regarded the social network as a complement to resource ownership in exerting power. In this case, the resource-based power was the primary source of power in tourism events, which had an important effect on stakeholder salience. The network-based power was a secondary and supplementary source.

In summary, this case study was able to identify that the salience of event stakeholders based on their power was highly variable due to the different types of power they had. It reveals the power heterogeneity of the "interstakeholder group" as well 
as the "intrastakeholder group." This study contributes to the development of descriptive stakeholder research (Donaldson \& Preston, 1995) in event tourism and proposes a more specific model for stakeholder power identification.

\section{Managerial Implications}

Events are resource dependent and involve a network of stakeholders. This presents potential challenges and issues, which are considered endemic to event organization, and affects their success or failure (Getz, 2002). Not all stakeholders are equal in terms of their capacity, opportunity, and willingness to cooperate or threaten the events (Savage et al., 1991). Identifying stakeholders and their associated powers is an important part of event management and can prepare the organizer to address possible issues arising from the imbalance of power (Andersson \& Getz, 2007).

It is very important for the organizer to secure continuing support from the external executive and asset-based stakeholders through continual communication and relationship building. At the same time, they need to monitor the building and possible exploiting of power by strong players; to avoid being surprised by power plays and having to constantly seek alternative suppliers and resources so that their cost of associating with the powerful stakeholders does not increase (Andersson \& Getz, 2007). A good example in this case study would be the growing dependence on the venue supplier to provide the venue and facilities, and to manage the food and craft mart. The increased monopoly that this stakeholder has in the food mart may affect the selection and pricing of food available on site, hence affecting the service experience of event goers. The organizer should be vigilant of such change. Dependence on one or a few stakeholders for critical resource is a definite risk, as it leaves the event vulnerable if those stakeholders withdraw support. Where dependency is high, the event might be forced to change in response to the demands of its critical resource providers (Getz, 2002; Pfeffer \& Salancik, 2003). The dependability of the event organizer on asset-based stakeholders could impact upon the financial and operational success of the event and present a significant challenge for the event organizer. Interestingly, in this case study, this group of stakeholders seldom exercised the strong power they possessed. They remained in the network but did not try to influence strategic or operational matters, perhaps because of their mutual dependence and reciprocal relationships over the years.

On the other hand, the large number of diffuse stakeholders in this study might be the most legitimate stakeholders in tourism events because they were the intended beneficiaries of the event. However, due to their lack of power to influence the event management, their interests were neglected. Notwithstanding, diffuse stakeholders may exercise their power through passive resistance and a withdrawal of support from the events (Clarke \& Jepson, 2011). Ford et al. (2012) proposed forming more allies and collaborators with less powerful stakeholders as a strategy to increase both the power of diffuse stakeholders and the event organizer's own power. Likewise, the relationship with referral stakeholders could be strengthened by making them the media partners or sponsors of the event to receive free or augmented promotion, heighten the event brand value, prevent risk of negative publicity, and increase the legitimacy of the event at the destination (Getz et al., 2007; Prebensen, 2010).

To sustain itself in the long term, tourism events have to avoid becoming too dependent on corporate sponsorship and a limited number of resource providers. Similarly, a high dependency on public funding leads to high public scrutiny on event impacts at the destination. The event tourism benefits should be demonstrated and equitably distributed to local tourism businesses. Reed (1997) and Nunkoo and Ramkissoon (2012) pointed out that power disparities and concentration at the destination may inhibit positive effects of, and satisfaction with, cooperation. The event organizers should consult and engage more tourism businesses-particularly in the planning and marketing processes. More direct involvement from peripheral members of the tourist industry in the ownership of the event would be necessary, to pool the limited resources at the destination and to tap into the wider tourism players' network to achieve the common goal of attracting more visitors to the destination. In view of rising competition from other regional music festivals, a cooperative relationship among tourism players would be desirable in defending and creating more 
value to both the event and their individual businesses. Getting more visitors could mean increased ticket revenue to the event, which in turn would reduce the need for public subsidy and-at the same time-lead to more business at the destination for local enterprises. Such a coopetition relationship is, in fact, the most mutually advantageous to all stakeholders (Wang \& Krakover, 2008). To sum up, diffuse stakeholders should not be forgotten as stakeholder influence is neither static with regards to resources nor the network position. The combined power of many diffuse stakeholders may cause substantial consequences for the event, either positive or negative (Pajunen 2006).

\section{Conclusion}

This study responded to Getz and Andersson's (2010) call for further research on event stakeholder relationships in developing and non-Western countries (i.e., countries that have clear ethnic, linguistic, and sociopolitical differences from the event destinations, which have been more typically researched to date). In this exploratory study, this article has examined stakeholder power in the organization of a tourism event, with the aim of advancing the stakeholder power concept within event tourism studies. It has been informed by an empirical case study approach. The case study examined a music festival in Malaysian Borneo, collecting data from stakeholder interviews, field visits, documentary, and web-based sources. Two conceptsresource dependency and network position-offer an explanation for the differences in stakeholder power. Their application has resulted in identification of four different types of stakeholder power: executive, asset based, referral, and diffuse.

The study echoed Larson and Wikstrom's (2001) illustration of stakeholder relational interaction in events as being "political.” The control of resources can exist in all four typologies; however, some resources are more critical and essential, whereas some resources are substitutable or replaceable. In terms of network position in the event organization, some stakeholders occupied a more central position, and some were marginal. More importantly, the findings highlighted that control of critical resources is more important than network centrality in generating power for the stakeholders in an event organization. The more types of stakeholders present and the greater the amount of critical resources a stakeholder controls, the more power that stakeholder possesses. Being a single case study and exploratory in nature is the limitation of this study. There is then a need to replicate this study and further examine the proposed framework in other Southeast Asia countries and for different types of events. Interviews with a wider span of stakeholder type would be beneficial. Nonetheless, the study offers researchers and managers insights into the complexities of stakeholder power relationships in tourism events. It represents a basis for further research still needed to better understand the nature of stakeholder power in tourism events. Longitudinal studies would be valuable to study any potential change of stakeholder power over different event life cycles. It is also necessary for the event managers to identify and manage powerful stakeholders, and to develop strategies to sustain input and collaboration from different stakeholders in staging the event. Such proactive measures are essential in ensuring long-term sustainability of tourism events.

\section{References}

Allen, J., O’Toole, W., Harris, R., \& McDonnell, I. (2011). Festival \& special event management (5th ed.). Milton, Qld: John Wiley.

Andersson, T., \& Getz, D. (2007). Resource dependency, costs and revenues of a street festival. Tourism Economics, 13(1), 143-162.

Beritelli, P., \& Laesser, C. (2011). Power dimensions and influence reputation in tourist destinations: Empirical evidence from a network of actors and stakeholders. Tourism Management, 32(6), 1299-1309.

Church, A., \& Coles, T. (2007). Tourism, power and space. London: Routledge.

Clarke, A., \& Jepson, A. (2011). Power and hegemony within a community festival. International Journal of Event and Festival Management, 2(1), 7-19.

Clarkson, M. B. E. (1995). A stakeholder framework for analyzing and evaluating corporate social performance. The Academy of Management Review, 20(1), 92-117.

Cooper, C., Scott, N., \& Baggio, R. (2009). Network position and perceptions of destination stakeholder importance. Anatolia, 20(1), 33-45.

Creswell, J. W. (2003). Research design: Qualitative, quantitative, and mixed methods approaches (2nd ed.). Thousand Oaks, CA: Sage.

Donaldson, T., \& Preston, L. E. (1995). The stakeholder theory of the corporation: Concepts, evidence, and 
implications. The Academy of Management Review, 20(1), 65-91.

Eisenhardt, K. M. (1989). Building theories from case study research. Academy of Management Review, 14(4), 532-550.

Etzioni, A. (1964). Modern organizations. Englewood Cliffs, NJ: Prentice-Hall.

Ford, R. C., Peeper, W. C., \& Gresock, A. (2009). Friends to grow and foes to know: Using a stakeholder matrix to identify management strategies for convention and visitors bureaus. Journal of Convention \& Event Tourism, 10(3), 166-184.

Ford, R. C., Wang, Y., \& Vestal, A. (2012). Power asymmetries in tourism distribution networks. Annals of Tourism Research, 39(2), 755-779.

Freeman, L. C. (1979). Centrality in social networks conceptual clarification. Social Networks, 1, 215-239.

Freeman, R. E. (1984). Strategic management: A stakeholder approach. Boston, MA: Pitman.

Getz, D. (2002). Why festivals fail. Event Management, 7(4), 209-219.

Getz, D. (2005). Event management \& event tourism (2nd ed.). New York: Cognizant Communications Corp.

Getz, D., \& Andersson, T. (2010). Festival stakeholders: Exploring relationships and dependency through a fourcountry comparison. Journal of Hospitality and Tourism Research, 34(4), 531-556.

Getz, D., Andersson, T., \& Larson, M. (2007). Festival stakeholder roles: Concepts and case studies. Event Management, 10(2), 103-122.

Gulati, R., (1999). Network location and learning: The influence of network resources and firm capabilities on alliance formation. Strategic Management Journal, 20(5), 397-420.

Hazra, S., Fletcher, J., \& Wilkes, K. (2014). An evaluation of power relationships among stakeholders in the tourism industry networks of Agra, India. Current Issues in Tourism, 1-17.

Izzo, F., Bonetti, E., \& Masiello, B. (2012). Strong ties within cultural organization event networks and local development in a tale of three festivals. Event Management, 16(3), 223-244.

Jamal, T. B., \& Getz, D. (1995). Collaboration theory and community tourism planning. Annals of Tourism Research, 22(1), 186-204.

Kim, J., Boo, S., \& Kim, Y. (2013). Patterns and trends in event tourism study topics over 30 years. International Journal of Event and Festival Management, 4(1), 66-83.

Larson, M. (2002). A political approach to relationship marketing: Case study of the Storsjoyran Festival. International Journal of Tourism Research, 4, 119-143.

Larson, M. (2009). Joint event production in the jungle, the park, and the garden: Metaphors of event networks. Tourism Management, 30(3), 393-399.

Larson, M., \& Wikstrom, M. E. (2001). Organising events: Managing conflict and consensus in a political market square. Event Management, 7(1), 51-65.
Lee, J., \& Beeler, C. (2009). An investigation of predictors of satisfaction and future intention: Links to motivation, involvement, and service quality in a local festival. Event Management, 13(1), 17-29.

Lincoln, Y. S., \& Guba, E. G. (1985). Naturalistic inquiry. Beverly Hills, CA: Sage.

Marzano, G., \& Scott, N. (2009). Power in destination branding. Annals of Tourism Research, 36(2), 247-267.

Miles, M. B., \& Huberman, A. M. (1994). Qualitative data analysis: An expanded sourcebook (2nd ed.). Thousand Oaks, CA: Sage.

Mitchell, R. K., Agle, B. R., \& Wood, D. J. (1997). Toward a theory of stakeholder identification and salience: Defining the principle of who and what really counts. The Academy of Management Review, 22(4), 853-886.

Myers, M. D. (2009). Qualitative research in business and management. London: Sage.

Nunkoo, R., \& Ramkissoon, H. (2012). Power, trust, social exchange and community support. Annals of Tourism Research, 39(2), 997-1023.

Pajunen, K. (2006). Stakeholder influences in organisational survival. Journal of Management Studies, 43(6), 1261-1288.

Parent, M., \& Deephouse, D. (2007). A case study of stakeholder identification and prioritization by managers. Journal of Business Ethics, 75(1), 1-23.

Patton, M. Q. (2002). Qualitative research \& evaluation methods (3rd ed.). Thousand Oaks, CA: Sage.

Pfeffer, J. (1992). Managing with power: Politics and influence in organizations. Boston, MA: Harvard Business School Press.

Pfeffer, J., \& Salancik, G. R. (2003). The external control of organizations: A resource dependence perspective. Stanford, CA: Stanford Business Books.

Prebensen, N. K. (2010). Value creation through stakeholder participation: A case study of an event in the High North. Event Management, 14(1), 37-52.

Reed, M. G. (1997). Power relations and community-based tourism planning. Annals of Tourism Research, 24(3), 566-591.

Reid, S. (2011). Event stakeholder management: Developing sustainable rural event practices. International Journal of Event and Festival Management, 2(1), 20-36.

Reid, S., \& Arcodia, C. (2002) Understanding the role of the stakeholder in event management. In L. Jago, M. Deery, R. Harris, A-M. Hede, \& J. Allen (Eds.), Events and Place Making-International Event Research Conference (pp. 479-515). Australian Centre for Event Management, University of Technology Sydney, Sydney July $15-16$.

Rowley, T. J. (1997). Moving beyond dyadic ties: A network theory of stakeholder influences. The Academy of Management Review, 22(4), 887-910.

Saldana, J. (2013). The coding manual for qualitative researchers (2nd ed.). London: Sage.

Saunders, M., Lewis, P., \& Thornhill, A. (2009). Research methods for business students (5th ed.). Essex, UK: Prentice Hall. 
Savage, G. T., Nix, T. W., Whitehead, C. J., \& Blair, J. D. (1991). Strategies for assessing and managing organizational stakeholders. Academy of Management Executive, 5(2), 61-75.

Sheehan, L., Ritchie, J. R. B., \& Hudson, S. (2007). The destination promotion triad: Understanding asymmetric stakeholder interdependencies among the city, hotels, and DMO. Journal of Travel Research, 46(1), 64-74.

Spiropoulos, S., Gargalianos, D., \& Sotiriadou, K. (2006). The 20th Greek Festival of Sydney: A stakeholder analysis. Event Management, 9(4), 169-183.

Swanborn, P. G. (2010). Case study research: What, why and how? London: Sage.

Wang, Y., \& Krakover, S. (2008). Destination marketing: Competition, cooperation or coopetition? International
Journal of Contemporary Hospitality Management, 20(2), 126-141.

Weber, K., \& Ali Knight, J. (2012). Events and festivals in Asia and the Middle East/North Africa (MENA) region. International Journal of Event and Festival Management, 3(1), 4-8.

Xue, H., \& Mason, D. S. (2011). The changing stakeholder map of Formula One Grand Prix in Shanghai. European Sport Management Quarterly, 11(4), 371-395.

Yin, R. K. (2003). Applications of case study research (2nd ed.). Thousand Oaks, CA: Sage.

Yin, R. K. (2009). Case study research: Design and methods (4th ed.). Thousand Oaks, CA: Sage. 